\title{
Gender Diversity and LGBTQ Inclusion in K-12 through Higher Education
}

\author{
Alyson Mitchell'1 , Abigail Mitchell ${ }^{2}$ \\ ${ }^{1}$ Niagara University, Lewiston, NY, USA \\ ${ }^{2}$ D'Youville College, Buffalo, NY, USA \\ Email: abrn@aol.com
}

How to cite this paper: Mitchell, A., \& Mitchell, A. (2019). Gender Diversity and LGBTQ Inclusion in K-12 through Higher Education. Psychology, 10, 1595-1598. https://doi.org/10.4236/psych.2019.1012104

Received: July 24, 2019

Accepted: September 15, 2019

Published: September 18, 2019

Copyright $\odot 2019$ by author(s) and Scientific Research Publishing Inc. This work is licensed under the Creative Commons Attribution International License (CC BY 4.0).

http://creativecommons.org/licenses/by/4.0/

\begin{abstract}
People who identify as LGBTQ are members of every community and include people of all ages, including the younger generation. Lack of education, for this community, from kindergarten to higher education is not serving the Lesbian, Gay, Bisexual, Transgender, and Queer (LGBTQ) justice. Educators need to be aware of the terms related to sexual orientation and gender identity to be able to improve the educational process. The goal of this paper is to initiate the conversation between all educators and the educational community.
\end{abstract}

\section{Keywords}

LGBTQ, Education, Teaching Strategies

\section{Overview}

Students who identify as LGBTQ are members of every school community and include people of all ages, races, ethnicities, educational and socioeconomic backgrounds. According to the United States Department of Health and Human Services (HHS, 2017), those who do identify as LGBTQ are at a higher risk of substance use and abuse, obesity, mental health disorders, STDs including HIV/AIDS, physical or sexual abuse. Many young people contend with rejection, isolation, bullying, and other related stressors at school and even at home. These challenges can lead into a poor outcome. Every educator, parent, and community member has the ability to support LGBTQ individuals by learning about and practicing efforts to provide culturally competent awareness (McManus, 2008). Bullying starts at the young age, most of the time in Kindergarten. This population faces unique challenges and health disparities including homelessness, suicide, and drug abuse. The 2017 National School Climate Survey (http://www.glsen.org/nscs) 
(GLEN, 2018), demonstrates that bullying has gained popularity for the transgender and gender-nonconforming youth. Among the findings:

- $87.3 \%$ LGBTQ students experienced harassment or assault based on sexual orientation, gender expression, gender, and others. 7 out of 10 experienced verbal harassment at school;

- 2 out of 5 students avoid washrooms; more than 1/3 of LGBTQ students miss one day of school in the last month due to feeling unsafe;

- Verbal harassment based on gender expression increased from 2015 to 2017.

In the last few years, LGBTQ individuals in K-12 and higher education have gained increasing visibility and have made some improvements within their environment but not enough to stop the bullying. In higher education it is pertinent that diversity is acknowledged within the LGBTQ community as important as recognizing sexual orientation and gender diversity within the campus community as a whole (Reen, 2017).

\section{Teaching Strategies}

Increased education and awareness round the diversity in the LGBTQ student and a good understanding of the somewhat complex acronyms and language that a student may use to self-identify will assist to reduce the stigma and avoid unintended discrimination by educators. Table 1 has a short listing of some common terminology (Mitchell, Somers, Bauder, \& Lewis, 2018).

Table 1. A short listings of some common terminology.

\begin{tabular}{|c|c|}
\hline Asexual & Does not experience sexual attraction or desire. \\
\hline Pansexual & Can be attracted to any sex or gender. \\
\hline Binary system & $\begin{array}{l}\text { A system comprised of two opposing parts. Male/Female is a binary system for sex, } \\
\text { and man/woman is a binary system for gender. }\end{array}$ \\
\hline Gender & $\begin{array}{l}\text { Complex: influenced by each of the gender terms below, based on emotional, } \\
\text { behavioral, and cultural characteristics. }\end{array}$ \\
\hline Gender identit & $\begin{array}{l}\text { Our internal, personal sense of what our gender is, is one view, everyone has gender } \\
\text { identity, like sexual orientation, gender identity can be conceptualized as infinite } \\
\text { points along a continuum. }\end{array}$ \\
\hline Gender fluid & $\begin{array}{l}\text { Gender identity that shifts, it may or may not be binary. A gender fluid individual } \\
\text { may feel like a man some days, and like a woman some days, they may or may not } \\
\text { also identify as non-binary as genderqueer, some or all of the time. }\end{array}$ \\
\hline Genderqueer & Individual acknowledges the "queer" in a persons' sense of self. \\
\hline Cisgender & $\begin{array}{l}\text { Individual who gender identity "matches" the sex of their body and the gender they } \\
\text { were assigned at birth. }\end{array}$ \\
\hline Agender & Individual who identifies as being without a gender. \\
\hline Transsexual & $\begin{array}{l}\text { Individual who seeks medical or surgical treatments as part of the process of } \\
\text { expressing their gender. }\end{array}$ \\
\hline Lesbian & $\begin{array}{l}\text { Individual who is a homosexual woman. The word lesbian is also used for women } \\
\text { in relation to their sexual identity or sexual behavior, regardless of sexual } \\
\text { orientation. Or same-sex attraction. }\end{array}$ \\
\hline Gay & Individual whose sexual orientation is the same sex. Often referred to the men only. \\
\hline Bisexual & Individual who is sexually attracted not exclusively to people of one particular gender. \\
\hline
\end{tabular}


Educators might feel uncomfortable however discussion of sexual orientation and gender identify is more common today than even five years ago. Example: the instructors' roster might say Thomas and the student answers please call me Tina. Or perhaps students are completing projects in the community and there are Men and Women bathrooms, what do you do? The correct action would be is to allow the student to use whatever bathroom they identify with, at the moment. What about teaching at the younger years, and trying to introduce reading material that all the students might be able to related to and reflect. One of the fastest and quickest ways to start the conversation at the early age, kindergarten, is through literature. Storytelling is a great way to introduce new ideas and topics to youngsters. Self-knowledge and awareness are at the root of all great storytelling (Peters, 2018). Great stories appeal to our deepest emotions; anger, disgust, fear, happiness, sadness and surprise. From elementary school to high school students, they all should be supplemented with books that have a LGBTQ focus. Educators can include literature and planned lessons around the topic to support the community and introduce the various topics. All children should learn about their community, and having students exposed to LGBTQ literature will increase acceptance and understanding by their peers. This should decrease the bullying and unsafe school environments. Examples of picture books for the younger ages: The day Joanie Frankenhauser became a boy, 10,000 dresses, Tango makes three, Julian is a Mermaid, Pink is for boys, and Red: A crayons Story. For the young reader: George, The Misadventures of the Family Flectcher, Dram, and Princess Ever After. Suggestions for the adolescent: When the Moon Was Ours, Unbecoming, With or Without You, and Love Drugged. There are also a few nonfiction books for the high school and college student: Respecting the Contributions of LGBT Americans, Branded by the Pink Triangle, and Gay America: Struggle for Equality.

\section{Best Practices for an Inclusive Community}

All educators should be educated about sexual identity and gender diversity in youth and how open communication is essential. Having supportive faculty and school administrators is crucial. Not tolerating any type of behavior that is inappropriate, this should start in Kindergarten. Improve whole school anti-bullying policy, by incorporating a bullying prevention and intervention program. Improve on supervision within the halls and other social gathering locations (Ekstrand, Lunn, \& Yehia, 2017). Introducing the LGBTQ community via storytelling and using the appropriate literature. Other strategies in the class room could be using U-tube and Ted talks. Schools and colleges should be free from hostile environments. In higher education campus could establish a campus wide steering committee that oversees student issues. Education is needed in all areas to decrease discrimination and increase acceptance.

\section{Conclusion}

Research suggests that education and sympathetic awareness of educators, par- 
ents, and the community can decrease sigma which decreases bullying. Teaching strategies such as the use of literature are important. The need to embrace the cultural shift is important. Improving the student-instructor relationship by creating a more welcoming classroom and inclusive environment will increase the trust and communication.

\section{Conflicts of Interest}

The authors declare no conflicts of interest regarding the publication of this paper.

\section{References}

Ekstrand, L., Lunn, M., \& Yehia, B. (2017). Applying Organizational Change to Promote Lesbian, Gay, Bisexual, and Transgender Inclusion and Reduce Health Disparities. LGBT Health, 4, 174-180. https://doi.org/10.1089/lgbt.2015.0148

GLEN (2018). National School Climate Survey Released. https://www.glsen.org/nscs

HHS (2017). Healthy People 2020. US Department of Health and Human Services. http://www.healthypeople.gov

McManus, A. (2008). Practical Implications for NPs. The American Journal for Nurse Practitioners, 12, 29-39.

Mitchell, A., Somers, M., Bauder, A., \& Lewis, D. (2018). Healthcare Professionals Working with LGBTQ Patients. Journal of Advances in Medicine and Medical Research, 25, 1-5. https://doi.org/10.9734/JAMMR/2018/40721

Peters, B. (2018). 6 Rules of Great Storytelling. https://medium.com

Reen, K. (2017). Students on Campus: Issues and Opportunities for Higher Education Leaders. 